\title{
Feasibility Study of The Wechsler Intelligence Scale For Children (WISC) Intelligence Test Application for Children with Hearing Impairment
}

\author{
Hari Karyono, Ana Rafikayati \\ Education Technology \\ PGRI Adi Buana Surabaya University \\ Surabaya, Indonesia \\ harikaryono@unipasby.ac.id, ana.rafikayati@gmail.com
}

\author{
Mudhar \\ Guidance and Counseling Department \\ PGRI Adi Buana Surabaya University \\ Surabaya, Indonesia \\ mudhar.bps@gmail.com
}

\begin{abstract}
The purpose of this study was to know the feasibility of Wechsler Intelligence Scale for Children (WISC) intelligence test application for children with hearing impairment. This study used quantitative descriptive research. The subjects in this study were 2 psychologists, 2 media experts (design), and 2 sign language interpreters. This study used questionnaire to measure the feasibility of intelligence test applications in terms of content, design, and readability in the form of a Likert scale which has 5 scores. The data were evaluated according to the feasibility criteria of the rating with the score of $0.00-5.00$. Based on the results of data analysis, the feasibility of the intelligence test application from content experts was 3,538 (feasible), design expert was 4 (very feasible) and feasibility of readability was 3,945 (feasible). Based on the results of the data analysis, it can be concluded that the application of intelligence tests for children with hearing impairment is appropriate to be used by the tester (psychologist) as an intelligence test instrument that can be used in measuring intelligence of children with hearing impairment.
\end{abstract}

Keywords - Intelligence Test Application, WISC, Children with Hearing Impairment.

\section{INTRODUCTION}

Intelligence is the potential within a human that affects a person's ability in various fields. Intelligence plays a role in storing and binding information, constructing concepts, capturing relationships and making conclusions, processing materials and constructing a combination of them (Spearman in [1]). Pintner and Patterson (1917) in [2] stated that based on the results of his research on the children with hearing impairment groups, it is known that the IQ of children with hearing impairment is at the level of mental retardation.

The same thing was also found when they did research in 1924; the IQ of children with hearing impairment was under normal children (listening children). reported on the results of investigations of the results of children with hearing IQ test in 1930-1967. It is found that most of the results showed the same results that IQ of children with hearing impairment was lower than hearing children especially for profound hearing impairment.

Although there have been many studies suggested that children with hearing impairment intelligence is below average, it should be re-analyzed about the instrument that is used in measuring IQ of children with hearing impairment. This is accordance with the opinion of [2] which stated that based on the Milan conference of 1988, there are many biased studies from psychologists. IQ measurement consists of bias in test methods, subject research, and the lack of experience of the tester.

The intelligence characteristics of children with hearing impairment generally have the same IQ score distribution as hearing children [3]. Even if there are difficulties that arise, more associated to talk, read and write but those things are not related to the level of intelligence. This is in accordance with the opinion of [4] which states that in general, the intelligence of children with hearing impairment is not different with other children (hearing children). So, just like other children, children with hearing impairment have superior intelligence, average and below average.

For now, the most commonly intelligence test that is used is still a verbal intelligence test instrument. So when children with hearing impairment are tested for intelligence with those instruments, the results are below average. This happens not because their intelligence is low, but because the measuring instrument used cannot measure their intelligence appropriately. Children with hearing impairment experience difficulties in language due to hearing loss. [5] stated that to measure the intelligence of children with hearing impairment appropriately, the test instrument should be made in the form of performance test, such as test board, picture completion, block design and other forms that are more visual. In addition, the tester should also be a person who experienced in interacting with children with hearing impairment.

Based on the explanation, it is known that there is often an inaccuracy in intelligence measurement of children with hearing impairment. This is because the existing test instruments do not accurately measure the intelligence of the 
child because of the instruction is in verbal while children with hearing impairment experiences a disruption to language development and verbal communication. Therefore, it is necessary to develop intelligence test instruments that are adjust to the characteristics of children with hearing impairment.

The Wechsler Intelligence Scale for Children (WISC) intelligence test is one of the most commonly used in the world of psychology. The WISC test is the most commonly used by psychologists. Based on interviews with 30 psychologists at the Indonesian Psychology Association of East Java on January 16, 2016 about the intelligence test instrument used, 13 psychologists stated often use WISC, 11 psychologists use Binet Simon and 6 psychologists use other test instrument.

The WISC intelligence test is an intelligence test for children aged 8-15 years. This test consists of 2 types of tests, namely verbal tests and performance tests. Verbal tests consist of material information, understanding, counting, equality, vocabulary, range of numbers. While the performance test consists of completing the picture, set the picture, designing the block, assemble objects, symbols, and mazes [1]. In implementing the WISC test for children with hearing impairment, many experts use modification and adaptation. Some experts choose to use only performance tests and some still use both (verbal and performance) with some modifications such as adding pictures. Nevertheless, no specific rules have been patented so it is not known which test model is the most suitable children with hearing impairment.

Based on that explanation, the need for intelligence tests for children with hearing impairment has not been met. This encourages researchers to conduct research on this. With the development of this intelligence test instrument, it is expected that IQ of children with hearing impairment can be measured accurately by measuring instrument that is accordance with the characteristics of children. So that education services can be provided in accordance with their potential and children with hearing impairment can develop optimally. The purpose of this study was to know the feasibility of Wechsler Intelligence Scale for Children (WISC) intelligence test application for children with hearing impairment.

\section{METHOD}

This study used quantitative descriptive research. The subjects in this study were 2 psychologists, 2 media experts (design), and 2 sign language interpreters. This study used questionnaire to measure the feasibility of intelligence test applications in terms of content, design, and readability in the form of a Likert scale which has 5 scores. Score 5 was for the very good category, score 4 for the good category, score 3 for the enough category, score 2 for the less category and score 1 for the bad category. The data analysis technique used in this research was the data analysis formula according to Riyanto in [6]. The formula is below.

$$
\text { feasibility }=\frac{\text { sum of all item scores }}{\text { the number of items }}
$$

Then the data were evaluated according to the feasibility criteria of the rating below.

TABLE I. FeAsibILITY VALUE

\begin{tabular}{|c|c|}
\hline Category & Feasibility \\
\hline $4.0-5.00$ & Very feasible \\
\hline $3.0-3.99$ & Feasible \\
\hline $2.0-2.99$ & Enough feasible \\
\hline $1.0-1.99$ & Less feasible \\
\hline $0.0-0.99$ & Not feasible \\
\hline
\end{tabular}

\section{RESUlT AND DisCUSSION}

Feasibility results were obtained from expert validation results (content, design, and readability). Based on the results of the content expert questionnaire, a total score of 46 was obtained. After the questionnaire was filled in by the content expert, then data analysis was carried out. The result of the content validation questionnaire data analysis was 3.538. After knowing the feasibility results through data analysis then the results were interpreted through a list of eligibility criteria which can be seen in Table 1. Based on the list of criteria in Table 1, it can be concluded that the content validation results of the WISC intelligence test application for children with hearing impairment got a value of 3.538, It means that this application is in the feasible category in terms of content.

Based on content expert validation, it can be concluded that WISC intelligence test application for children with hearing impairment was feasible. This is consistent with the suitability of application content with WISC content. The Wechsler Intelligence Scale for Children (WISC) intelligence test is one of the most frequent and commonly used tests in the world of psychology. The WISC test is the intelligence test most often used by psychologists. The WISC intelligence test is an intelligence test for children aged 8-15 years. This test consists of 2 types of tests, namely verbal tests and performance tests. Verbal tests consist of information material, understanding, calculation, equation, vocabulary, range of numbers. While the performance test consists of completing images, arranging images, designing blocks, assembling objects, symbols, and mazes [1].

In the implementation, the development of intelligence test application for children with hearing impairment was in accordance with WISC content. The modified part was a verbal test, while the performance test had no change. This application has been adapted to the needs of children with hearing impairment. This is in accordance with the opinion of [5] which states that in the implementation of the WISC test for children with hearing impairment, many experts use modifications and adaptations. Some experts choose to only use performance tests and some are still using both (verbal and performance) with some modifications such as adding images.

By using the WISC test application for children with hearing impairment, whose development directed at the development of non-verbal test which was adapted to the characteristics of children with hearing impairment, the IQ of children with hearing impairment can be measured properly so that educational services can be provided in accordance with 
the potential possessed and children with hearing impairment can develop optimally.

Based on the results of the content expert questionnaire, it was obtained a total score of 52. After the questionnaire was filled in by the design expert then data analysis was carried out. The results of the design validation questionnaire data analysis was 4. After the feasibility results are known through data analysis, the results were interpreted through a list of eligibility criteria (See Table 1). Based on the list of eligibility criteria in Table 1, it can be concluded that the results of the validation of the WISC intelligence test application design for children with hearing impairment got a score of 4 , which means that this application is in the very feasible category in terms of design.

This intelligence test application for children with hearing impairment is developed by combining sign language videos using Macro Media Flash applications. Application with 11 chapters, namely: (1) information, (2) comprehension, (3) arithmetic, (4) similarities, (5) vocabulary, (6) digit span, (7) picture completion, (8) picture arrangement, (9) block design, (10) object assembly, and (11) coding. In its implementation this application was able to calculate the results of the final score from the results of the children with hearing impairment IQ measurement. This application can also be used on the touch screen gadget. This certainly can facilitate the tester in its use because the tester can use it via tablet or Android hand phone that is easy to use everywhere.

Based on the readability questionnaire results it was obtained a score of 3.945. After the results of the feasibility analysis are known through data analysis, the results were interpreted through a list of eligibility criteria. Based on the list of eligibility criteria, it can be concluded that the results of the WISC intelligence test application for children with hearing impairment was in the feasible category.

In terms of language, some adjustments were made including: instruction using short sentences. [7] stated that due to hearing impairment, children with hearing impairment have difficulties in communicating verbally, both expressively (speaking) and receptive (understanding the speech of others). This situation causes children with hearing impairment to experience obstacles in communicating with other people's environment. On verbal intelligence tests, children with hearing impairment were less able to demonstrate their abilities because of the developmental language disorders. Considering these conditions, in conducting intelligence tests for children with hearing impairment, the language that is easy to understand must be used. The choice of words (diction) should use shorter words and words that are often used by children every day.

In addition to using short sentences, this application is also equipped with videos. Children with hearing impairment understand what they see, not from what they hear. Therefore, often children with hearing impairment are referred to as "vision people". With such conditions, children with hearing impairment need more time in the learning process, especially for the subjects that are verbalized [4]. Intelligence aspects that are verbal-based are often low, but intelligence aspects that are based on vision and motor skills will develop rapidly [5]. In conducting intelligence tests for children with hearing impairment, it is necessary to make adjustments (adaptation) according to the characteristics of the children, one of them is through visual adaptation. Although children with hearing impairment have language barriers, children with hearing impairment have no problems with their visual and motor skills. Given these conditions, it is necessary to modify the instructions that are initially verbal to visual. Visual instructions can be performed in various ways, for example with the help of pictures or through videos.

This intelligence test application for children with hearing impairment used sign language. Sign language is a language that prioritizes manual communication through body language or through lip movement. Sign language usually combines the shape of the hand, the orientation of the movements of the hands, arms, lips or gestures and expressions of facial expressions to express things that are in mind. Sign language is used because children with hearing impairment generally communicate using sign language.

This is because the way of understanding language in children with hearing impairment is different from the way of understanding people in general. This is in accordance with the opinion of [5] who states that vocabulary in language cannot be explained through audio learning because of the inability to hear. One language learning for children with hearing impairment is to maximize the visual senses as a tool in receiving language information stimuli, and the use of sign language as a way of training communication with hearing impaired children. The stimulation of information is in the form of visualizing words into the form of pictures as a substitute for the audio method for people to hear. The sign language used in the intelligence test application for children with hearing impairment was the sign language Indonesian Language System (SIBI).

\section{CONCLUSION}

Based on the results of data analysis, the feasibility of the intelligence test application from content experts was 3,538 (feasible), design expert was 4 (very feasible) and feasibility of readability was 3,945 (feasible). Based on the results of the data analysis, it can be concluded that the application of intelligence tests for children with hearing impairment is appropriate to be used by the tester (psychologist) as an intelligence test instrument that can be used in measuring intelligence of children with hearing impairment.

\section{REFERENCES}

[1] N. Nur'aeni, Tes Psikologi: Tes Intelegensi dan Tes Bakat. Yogyakarta: Pustaka Pelajar, 2012.

[2] M. Vernon, "Fifty years of research on the intelligence of deaf and hardof-hearing children: A review of literature and discussion of implications," J. Deaf Stud. Deaf Educ., vol. 10, no. 3, pp. 225-231, 2005.

[3] R. M. Gargiulo, Special education in contemporary society: An introduction to exceptionality. Sage, 2010.

[4] S. Somantri, Psikologi Anak Luar Biasa. Bandung: PT. Refika Aditama, 2007. 
[5] M. Efendi, Pengantar Psikopedagogik Anak Berkelainan. Jakarta: PT Bumi Aksara, 2006.

[6] L. Leksono and Dkk, "Pengembangan Media Pembelajaran Berbantuan Komputer untuk SMA Pada Materi Amfibi," J. Inov. dan Perkayasa Pendidik., vol. 1, no. April, 2010.
[7] W. Wagino and A. Rafikayati, "Pelaksanaan Auditory Verbal Therapy (AVT) dalam mengembangkan keterampilan berbahasa anak tunarungu," J. Pendidik. Luar Biasa UNESA, vol. 9, no. 1, 2013. 